\title{
Physical Chemical Characteristics of the Local Water Facilities of the City of Kraljevo
}

\author{
DRAGAN D. MARINOVIĆ, Department of Public Health, Kraljevo \\ Professional paper \\ ZORAN M. MILIĆEVIĆ, University of Kosovska Mitrovica \\ UDC: 628.17.033(497.11) \\ Faculty of Economics, Kosovska Mitrovica \\ DOI: 10.5937/tehnika1905751M \\ ZORKA R. JUGOVIĆ, High Professional Railway School, Belgrade \\ MARINA T. STOJANOVIĆ, University of Niš, \\ Faculty of Occupational Safety, Niš \\ DUŠANKA D. MARINOVIĆ, Military Medical Academy, Belgrade
}

The largest part of the population of the city of Kraljevo and its surroundings is supplied with drinking water from the available pumping stations. The rural population of the city of Kraljevo is supplied with drinking water from rural waterworks [1]. A large number of the population of the city of Kraljevo and its surroundings are supplied with drinking water from a large number of local water bodies that represent roughly captured springs, where water quality monitoring has not been established, and many are left to the tooth of time. This work treats 10 local water bodies. Local water facilities are located either in the city of Kraljevo or in its surroundings. Continuous monitoring of the physical and chemical quality of water at some of the most important sites determined the physical chemical status of water in these local water bodies, variation and potential threat to quality due to external influences. The results of this monitoring can be used for the protection and rehabilitation of local water facilities, which would also protect the population.

Key words: local water facilities, water quality, physical chemical parameters

\section{INTRODUCTION}

For the whole world, water is of great importance and without it there is no life. That's why water must have good hygienic properties and all elements of health care.

Planet Earth represents our environment and the goal of all civilizations is to provide a quality life in a given environment.

Environmental pollution is a consequence of rapid urbanization, industrialization, traffic development and intensive agricultural production with the introduction of new technologies, resulting in a disproportion between the growth of the human population and the restoration of the necessary natural resources.

The problem of water protection is an integral part of the overall problem of protection, improvement and

Author's address: Dragan Marinović, Department of Public Health, Kraljevo, Slobodana Penezića 16

e-mail: dragan.marinovic@zjzkv.org.rs

Paper received: 12.04.2019.

Paper accepted: 04.09.2019. preservation of the environment. Water protection has a wide and complex problem, i.e. it is interdisciplinary.

The environmental protection system should ensure the protection of all spheres of the environment. Water protection has a wide and complex problem, which indicates that it cannot be classified into a single scientific discipline, but goes into the domain of different border disciplines. Due to the more serious and visible consequences of pollution, a wide front battle has been opened to eliminate and prevent further environmental degradation, and for a healthy environment.

Water quality depends on natural factors and human activity, as well as the regulation of the catchment area itself. Accelerated and large increase in population leads to increased demand for water in life and food production. This is also a decisive factor for universal care for water conservation.

Intensive development of agriculture and the increasing use of chemical agents leads to the occurrence of large quantities of toxic substances in water.

All natural resources: water, agricultural, construction and forest land, walls, minerals, fossil fuels, climate 
(sun, wind, tide and rain), flora and fauna are today increasingly endangered.

Water pollution can be considered as the most serious, because water is largely linked to food, energy and environmental issues. Bearing this in mind, water in Dublin in 1992. was characterized by the Water and Environment Conference as a „limited resource and economic good" that should be protected and managed so that the interests of future generations are not threatened, and in the same way to ensure its efficient and fair use. One of the important conclusions of this conference is that ,sustainability has become the basic principle of all development strategies, especially in the area of development of water resources" [1].

Water as the most important resource must be treated as ,good of general interest“ and must be used rationally, multi-purpose and multiple. When planning rational use of water, one must bear in mind the following:

- water is the most important precondition for the survival of all living beings on Earth;

- water is an irreplaceable, but also a renewable resource that is used in all processes as a raw material and as a means of working. That is why it is the only natural resource that is constantly in circulation as a general subject of work;

- only unpolluted water is health safe. It is therefore necessary to prevent its contamination;

- water is the most widespread natural resource, and therefore it is home to the most numerous biocenosis, and therefore is a key element of the environment that needs to be protected against pollution.

There are major disagreements and misunderstandings in the assessment of water resources, and it is therefore important to methodically clarify the issue of water as a resource that can be counted. Globally, there is a tendency of reducing water resources as resources over time due to ever-sharper ecological, urban and social constraints.

Misunderstandings stem from the ignorance of the fact that „water is present-a water resource“. Water as a resource has a quantity of less than the total water present in an area. The lack of water is manifested in different ways, but the following problems are especially noticeable [1]:

- there are increasing difficulties in providing the required quantities of water for all uses;

- the problems of protection against harmful activities of water are increasing and more serious;

- there is an increasing risk to man and his environment due to water pollution and the destruction of aquatic ecosystems.
Therefore, the Council of the European Union (EU) and the European Parliament in 1996 found that the objectives of a ,sustainable water policy“ should be provided in a "cost-effective and efficient way" as follows:

ensuring that drinking water supplies are safe;

that the water is of adequate quality and quantity in order to meet other economic needs;

- that the water source with its quality and quantity be such that it protects and maintains good environmental status and the functioning of the aquatic environment, as well as to meet the water needs of all ecosystems and habitats;

- that water management should be such as to prevent or reduce the negative impact of floods and droughts. Water management should be such that water can be used and loaded, and wastewater should be treated before discharge into recipients to a level that is not a threat to natural processes and to the restoration of water quality and quantity and which does not diminish the possibility of their multiple use.

The European Environmental Agency (EPA) concludes that an excessive amount of water is being consumed daily and that $20-40 \%$ of the affected quantity of water is wasted unnecessarily. It is therefore necessary to introduce a new approach to managing European water resources: reducing consumption by „disciplining“ consumers through a radical price increase. The reasons are that it is believed that already in 2070. on the European continent drought will be more a rule than an exception. A person is significantly polluting the environment by its activity, these pollution can have major consequences on the whole planet, and the most desertification is the desertification, the planet's transformation into the desert and the withdrawal of water into the depths, so it is necessary to take measures for the protection of water quality because the micro-pathogens present are carcinogenic.

\section{MATERIAL AND METHODS}

Drinking water tests from local water bodies are carried out according to the current Regulation on the hygienic correctness of drinking water („Official Gazette of FRY“ No. 42/98 and 44/99) [2], the Regulation on disinfection and examination of drinking water („Official Gazette of SRS“No. 60/81) and the Rulebook on the manner of taking samples and methods for laboratory analysis of drinking water (,Official Gazette of SFRY“ No. 33/87) [10] „By standard methods for testing hygienic correctness of water"[7] or Validated methods of the Public Health Institute of Kraljevo (VMK).

The hygienic correctness of drinking water from local water facilities was done by the contract of the city 
of Kraljevo and the Public Health Institute Kraljevo. facilities taken from ten locations over a period of ten The paper presents physical, chemical and micro- months. The obtained results of the correctness of dribiological results with ten local water bodies in the area nking water from the local water bodies of the city of of he city of Kraljevo for the period from 01.03.2018. Kraljevo are shown in Table 1. In Table 2, the chemical until 31.12.2018. years. Waters from local water faci- and microbiological defects of the local water facilities lities were sampled ten times, a total of 98 samples of the city of Kraljevo are given. The results are were made on physical chemical and microbiological graphically processed and shown in Figures 1 and 2. parameters.

The following local water objects were examined:

- The captured source „Mirina fes“ Kraljevo.

- The captured source „Ledina“ Kovači (near the court).

- Covered source „Mushroom“ Sokol.

- Captured source „Ul. Ribnic partisans“ Ribnica.

- Covered source „Popov potok“ Cibukovac.

- The captured source „Maglic“ (next to Kraljevo Raska).

- The captured source of the „Good Stranes“ (next to Kraljevo Raska).

- The captured source at the Žiče monastery (within the monastery circle).

- A source along the road to Kamenica (near Varevec).

- A captured source at the church in Vrbi (50 $\mathrm{m}$ from the church).

Local residents living near these local water facilities are supplied with drinking water from their sources or reservoirs, which are mostly occasionally cleaned and maintained. Most often, there is no person in charge of maintaining the reservoir, but locals work alone without professional help.

\section{RESULTS AND DISCUSSION}

The paper presents the results of the examined microbiological and physical chemical parameters in 98 tested samples of drinking water from local water facilities taken from ten locations over a period of ten months.

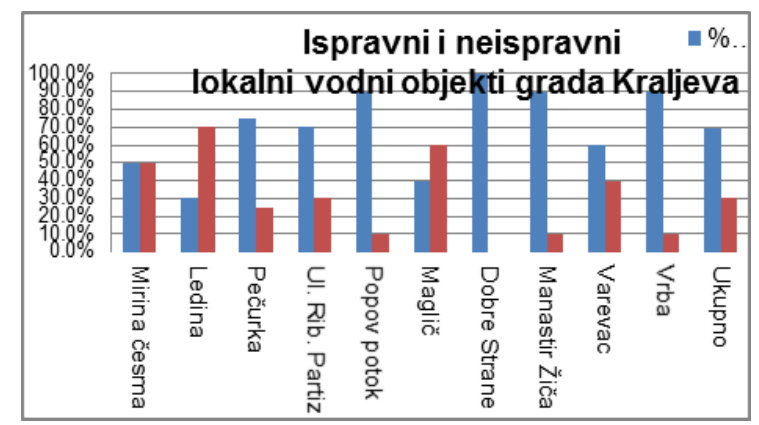

Figure 1 - Correct and defective local water objects of the city of Kraljevo

The paper presents the results of the examined microbiological and physical chemical parameters in 98 tested samples of drinking water from local water

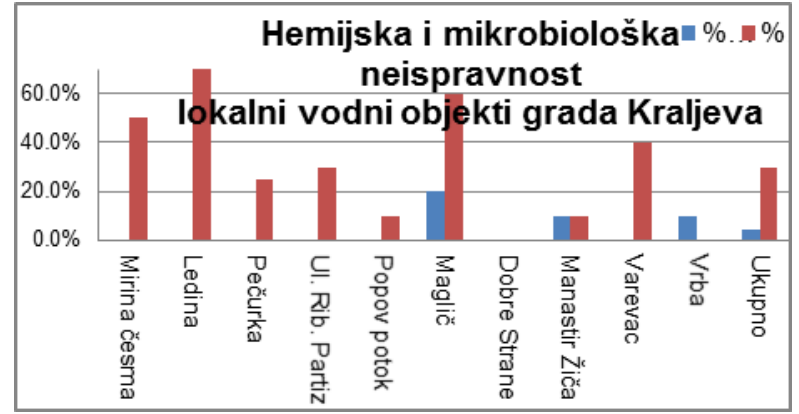

Figure 2 - Chemical and microbiological inaccuracy of local water facilities of the city of Kraljevo

The results of the examined microbiological and physical chemical parameters of water for drinking water of local water bodies in the city of Kraljevo and around the city of Kraljevo during 2018 give an overview of the current state of drinking water quality for local facilities. They show that the requirements of the Rulebook on hygienic correctness of drinking water (Official Gazette of FRY Nos. $42 / 98$ and 44/99) do not correspond to 30 samples of a total of 98 sampled waters. Out of the total number of samples tested, $30.6 \%$ is invalid for any criterion. Out of a total of 98 sampled drinking water for local water bodies, microbiological is incorrect $29.6 \%$ and chemically defective $4.1 \%$.

\section{Table 1. Percentage of correctness and incorrect of drinking water from the local water facilities of the city of Kraljevo}

\begin{tabular}{|l|l|l|}
\hline Site sampling & $\%$ correct & $\%$ incorrect \\
\hline Mirina fountain & $50,0 \%$ & $50,0 \%$ \\
\hline Ledina & $30,0 \%$ & $70,0 \%$ \\
\hline Mushroom & $75,0 \%$ & $25,0 \%$ \\
\hline Ul. Rib. Partiz & $70,0 \%$ & $30,0 \%$ \\
\hline Popov stream & $90,0 \%$ & $10,0 \%$ \\
\hline Maglic & $40,0 \%$ & $60,0 \%$ \\
\hline Good Pages & $100,0 \%$ & $0,0 \%$ \\
\hline Monastery Zica & $90,0 \%$ & $10,0 \%$ \\
\hline Varevac & $60,0 \%$ & $40,0 \%$ \\
\hline Vrba & $90,0 \%$ & $10,0 \%$ \\
\hline In total & $69,4 \%$ & $30,6 \%$ \\
\hline
\end{tabular}


Table 2. Percentage of chemical and microbiological incorrect in drinking water for local water facilities in the city of Kraljevo

\begin{tabular}{|l|l|l|}
\hline Site sampling & $\begin{array}{l}\% \text { shemically } \\
\text { incorrect }\end{array}$ & $\begin{array}{l}\% \text { microbiolo- } \\
\text { gically } \\
\text { incorrect }\end{array}$ \\
\hline Mirina fountain & $0,0 \%$ & $50,0 \%$ \\
\hline Ledina & $0,0 \%$ & $70,0 \%$ \\
\hline Mushroom & $0,0 \%$ & $25,0 \%$ \\
\hline Ul. Rib. Partiz & $0,0 \%$ & $30,0 \%$ \\
\hline Popov stream & $0,0 \%$ & $10,0 \%$ \\
\hline Maglic & $20,0 \%$ & $60,0 \%$ \\
\hline God Pages & $0,0 \%$ & $0,0 \%$ \\
\hline MonasterzZica & $10,0 \%$ & $10,0 \%$ \\
\hline Varevac & $0,0 \%$ & $40,0 \%$ \\
\hline Vrba & $10,0 \%$ & $0,0 \%$ \\
\hline In total & $4,1 \%$ & $29,6 \%$ \\
\hline
\end{tabular}

\section{CONCLUSIONS}

Based on the analysis of microbiological and physical chemical parameters, drinking water for local water bodies with ten places, both in the city itself and in the vicinity of the city of Kraljevo, can be concluded:

- $70 \%$ of the tested drinking water samples from local water facilities are microbiologically defective.

- Water chlorination in these local water facilities is of primary importance.

- Water chlorination is not a permanent solution to the drinking water quality of local water facilities, and it is therefore necessary to establish continuous disinfection and regular control of hygienic correctness of drinking water for local water bodies.

- The results of the examined waters of local water bodies should lead to communication with representatives of local communities and increased interest of locals for controlling drinking water as well as cleaning, arranging and maintaining their local water facilities.
- Water users from local water bodies should be aware that any sudden or extreme change in water flows, or hydrological and meteorological conditions, can cause a doubt that drinking water for local water bodies is likely to be defective for use and for water supply.

\section{REFERENCES}

[1] Dimitrijevic Z, Marinovic D, Dimitrijevic N, Rural waterworks in the territory of the city of Kraljevo, Proceedings Water and Sewerage'16, Vrdnik, pp. 7786, 2016.

[2] Kristoforovic-Ilic, Radovanovic M, Vajagic L, Jeftic Z, Folic R, Krnjetin S, Obrknezev R, Communal Hygiene, Prometheus, Novi Sad, 1998.

[3] Rulebook on the hygienic correctness of drinking water, Sl. list FRY, no. 42/98, 44/99.

[4] Tomaševic A. V, Milicevic Z. D, IV - Yugoslav Symposium, Chemistry and Enviromnmental Protection, Zrenjanin, 2001.

[5] Jovancicevic B, Long lasting organic pollutants, Faculty of Chemistry, Belgrade, 2006.

[6] Milosavljevic S. M, Structural Instrumental Methods, Faculty of Chemistry, Belgrade, 2004.

[7] Poček B, Drinking water, standard methods for testing hygienic correctness, NIR, Economic Review, Belgrade, 1990.

[8] Dalmatia B, Agbaba J, Klasnja M, editors.. Contemporary methods in the preparation of drinking water, I edition, Futura, Novi Sad, 2009.

[9] Marinovic D, Stojanovic M, Popovic D, Water Quality of Water Waterworks, Proceedings, Water and Sewerage'12, Vrsac, no. 156-164, 2012.

[10]Rulebook on the method of sampling and methods for laboratory analysis of drinking water, Fig list SFRJ, no. $33 /$

[11]Marinovic D, Savic V, Dimitrievic N, Stojanovic M, Popovic D, Quality of drinking water from rural waterworks after May floods in the year 2014 in the vicinity of Kraljevo, Proceedings, Water and Sewerage'15, Vrsac, no. 67-7, 2015. 


\section{REZIME}

\section{FIZIČKO HEMIJSKE KARAKTERISTIKE LOKALNIH VODNIH OBJEKATA GRADA KRALJEVA}

Najveći deo stanovništva grada Kraljeva i okoline se snabdeva vodom za piće iz raspoloživih crpnih stanica. Seosko stanovništvo grada Kraljeva se snabdeva vodom za piće iz seoskih vodovoda [1]. Veliki broj stanovništva grada Kraljeva i okoline se snabdeva vodom za piće iz velikog broja lokalnih vodnih objekata koji predstavljaju grubo kaptirana izvorišta, na kojima nije uspostavljen monitoring kvaliteta vode, a mnogi su prepušteni zubu vremena. Ovaj rad tretira 10 lokalnih vodnih objekata. Lokalni vodni objekti su locirani ili u samom gradu Kraljevu ili u njegovoj okolini. Kontinualnim praćenjem fizičko hemijskog kvaliteta vode na nekim od najvažnijih lokaliteta utvrđeno je fizičko hemijsko stanje voda na ovim lokalnim vodnim objektima, variranje i potencijalna ugroženost kvaliteta usled spoljašnjih uticaja. Rezultati ovakvog praćenja mogu se iskoristiti za zaštitu i sanaciju lokalnih vodnih objekata, čime bi se zaštitilo i stanovništvo.

Ključne reči: lokalni vodni objekti, kvalitet vode, fizičko hemijski parametri 